\title{
Functions of Subtitles in an Arabic Drama as an Agent of Language Acquisition for Students at The Faculty of Islamic Contemporary Studies UniSZA
}

Noor Eliza Abdul Rahman, Normila Noruddin, Noraihan Ali, Abdul Hakim Abdullah, Zulazhan Ab. Halim

To Link this Article: http://dx.doi.org/10.6007/IJARBSS/v11-i4/7971

DOI:10.6007/IJARBSS/v11-i4/7971

Received: 24 February 2021, Revised: 27 March 2021, Accepted: 14 April 2021

Published Online: 30 April 2021

In-Text Citation: (Rahman et al., 2021)

To Cite this Article: Rahman, N. E. A., Noruddin, N., Ali, N., Abdullah, A. H., \& Halim, Z. A. (2021). Functions of Subtitles in an Arabic Drama as an Agent of Language Acquisition for Students at The Faculty of Islamic Contemporary Studies UniSZA. International Journal of Academic Research in Business and Social Sciences, 11(4), 1312-1319.

Copyright: (c) 2021 The Author(s)

Published by Human Resource Management Academic Research Society (www.hrmars.com) This article is published under the Creative Commons Attribution (CC BY 4.0) license. Anyone may reproduce, distribute, translate and create derivative works of this article (for both commercial and non-commercial purposes), subject to full attribution to the original publication and authors. The full terms of this license may be seen at: http://creativecommons.org/licences/by/4.0/legalcode

Vol. 11, No. 4, 2021, Pg. 1312 - 1319

Full Terms \& Conditions of access and use can be found at http://hrmars.com/index.php/pages/detail/publication-ethics 


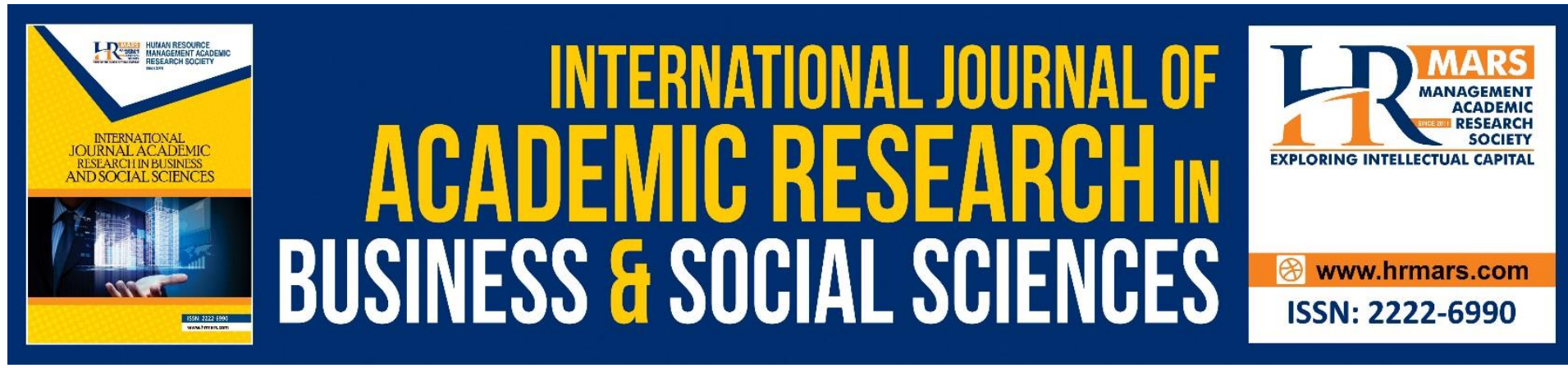

\title{
Functions of Subtitles in an Arabic Drama as an Agent of Language Acquisition for Students at The Faculty of Islamic Contemporary Studies UniSZA
}

\author{
Noor Eliza Abdul Rahman, Normila Noruddin, Noraihan Ali, \\ Abdul Hakim Abdullah \\ Faculty of Islamic Contemporary Studies, Universiti Sultan Zainal Abidin
}

\author{
Zulazhan Ab. Halim
}

Faculty of Languages and Communication, Universiti Sultan Zainal Abidin

\begin{abstract}
Translation is considered one of the strategies in learning a foreign language. Subtitles are a form of translation that involves audiovisual materials such as TV, video, CD and DVD. The relatively low level of vocabulary mastery among university students as such, led to the exploration of more effective Arabic language learning strategies. This study focused on the function of subtitles in improving Arabic vocabulary and clauses among students of the Faculty of Contemporary Islamic Studies, UniSZA. This study is a quantitative study that used Arabic language acquisition tests to obtain data. The study material is the subtitle texts of three episodes in an Arabic drama موسى كليم الله. The respondents were purposely chosen involving 23 Final Year students of Bachelor of Islamic Studies (Dakwah) with Honours at the Faculty of Islamic Contemporary Studies, UniSZA who are taking a course entitled alTarjamah, a translation course of Arab-Malay-Arab. Language acquisition tests consisting of vocabulary translation and translation clauses which were conducted in two sessions - before and after video viewing. The findings show that there is an increase in student vocabulary after viewing the video. In the vocabulary test, $30 \%$ of the students succeeded in scoring more than $50 \%$. The same grade level was also achieved by $78 \%$ of the students in the test clause. While the rest of the students also showed a moderate increase and the percentage of scores dropped after watching the video was zero. The improvement in this test score indicates that there is an increase in vocabulary and language acquisition among students through subtitle translation strategies.
\end{abstract}

Keywords: Arabic-Malay Translation, Clause, Language Acquisition, Subtitles, Translation Strategies, Vocabulary.

\section{Introduction}

Translation is observed as an essential field in the period of knowledge expansion and the development of information. It is a medium for transferring knowledge and information from 
one language to another. The process of applying knowledge and its dissemination in the nation must, of course, be carried out in its own language. This is because the transmission of knowledge done through native language allows the retention of originality of thinking and stimulates creativity of the native mind. Thus, translation becomes a channel that brings knowledge into a nation's education.

The role of translation is not limited to knowledge transfer and dissemination of information, but also contributes to foreign language learning. Various studies conducted in Malaysia have found that translation is a dominant strategy in learning that involves a foreign language (Nik Norimah \& Maheram, 2014; Harun, 2015). Harun (2017) argues that translation can be categorized as a dominant strategy needed by students in foreign language learning, especially among those who are with low and average learning ability.

Translation which is identified as the fifth skill in language learning, is an important social skill. This is because translation will encourage communication and understanding among students. Translation also allows students to be aware of the differences in vocabulary and grammatical elements that differ between the foreign language they are learning and their mother tongue (Norizah \& Sri Qamariah, 2017).

Language mastery is related to mastering vocabulary. Vocabulary is a collection of words contained in a language, which plays a role in shaping its lexical system (Nathesan, 2011). Issues of weaknesses in vocabulary are often cited as a major factor in the problem of language acquisition (Azani et al., 2012; Rosni, 2013; Nadwah \& Nadhilah, 2014). It is considered as one of the most important elements in language learning. This is because vocabulary is fundamental in the formation of phrases or sentences and thus leads to language mastery. Vocabulary mastery can be said to begin with the process of translating from a foreign language to a native language. The ability to translate from a native language to a foreign language is a measure of the achieved level of language acquisition.

\section{Learning Foreign Language Through Subtitles}

The process of translating these days is no longer confined to writing materials such as religious books, scholarly books, academic journals or literary works. Advances in science, technology and telecommunications have also affected the development of translation. This is because the rapid increase in digital technology has contributed to the surge of aired programmes from abroad. These imported programmes definitely require translation into the local language because without such translation, the storyline and message that these programmes want to convey will not be understood by the target audience. This phenomenon has created high demand in the field of translation for audio-visual materials such as TV (Television), movie, computer, VCD (Video Compact Disc) and DVD (Digital Versatile Disc). The process of producing translations for these materials is known as audio-visual translation.

The importance of translating a foreign show to local TV audience is beyond dispute. Subtitling is a form of audio-visual translation that is often found and most popular for its number of readers compared to other types of translations such as books, articles, magazines, etc. According to Al-Abbasi (2009), subtitling is a process of translating meaning in movies or TV series into words, which is usually shown at the bottom of the screen. The source dialogue is copied simultaneously into the target language to allow the target audience to understand 
the story. In short, a subtitle means the translation of a dialogue in movies that is broadcasted simultaneously with the movie and kept as briefly as possible through the editing process in order to meet the constraints of space and time (Eliza, 2014).

Besides delivering the message, subtitles also play a role in the process of language acquisition. This is because subtitles allow the audience to absorb the language used by native speakers compared to the more formal language learning methods. While reading subtitles, the audience subconsciously compares the presented content in two different languages in the form of audio and written before learning the language that they do not understand. Based on a survey conducted, Hasuria (2006: 149) observes that subtitles are the most commonly used language transfer method for TV programmes, especially for English programs, followed by foreign language programmes such as Mandarin/Cantonese, Hindi/Tamil/Urdu, Arabic and Spanish. This is reinforced by Radiah and Hasuria (2009: 539) on a group of students who major in languages other than English in an institute of higher learning. Based on the feedback survey respondents, drama or foreign language programme, along with Malay subtitles, provide new knowledge about a new language in addition to indirectly help increase foreign language proficiency.

\section{Research Objectives}

This study outlined two objectives that must be met:

1. Identify levels of vocabulary and Arabic clauses among UniSZA students

2. Measure the extent to which subtitles can help students in acquiring Arabic

\section{Research Methodology}

This study is a quantitative study that used Arabic language acquisition tests to obtain data. The materials for this research is an animated three-episode drama entitled Arabic موسى كليم الله which is given subtitles in Malay. This drama is chosen because it has good subtitles in terms of vocabulary selection, sentence selection and conveying messages. The episodes of each episode lasted approximately seven minutes and were repeated four times. The selected episodes were episodes 9, 13 and 30. These episodes were selected because they featured moments in the story of Prophet Moses as recorded in the Quran as well as the prophets' biography such as the incident when Prophet Moses was swept into the river, he yanked Pharaoh's beard, he took the coals and drowned Pharaoh in the Red Sea. The respondents were purposely selected, involving 23 students from the Bachelor of Islamic Studies (Dakwah) with Honors at the Faculty of Islamic Contemporary Studies, UniSZA who are taking courses al-Tarjamah, a translation course Arab-Malay-Arab. The language acquisition test was divided into two parts, namely vocabulary tests and clause tests. The test was conducted in two sessions, both before the student watched the video and after the video finished.

\section{Data Analysis}

The data analysis was divided into two parts. The first part is the comparative analysis of students' achievement scores before and after watching the video. The comparative analysis was based on vocabulary tests and clauses of the chosen episodes. The second part was an analysis of individual achievement in overall vocabulary questions and clauses. This analysis was performed to see how subtitles function as a language acquisition agent for each individual. The analysis is shown in the following tables: 


\section{Achievement analysis of students' test results after watching the video compared to before watching video.}

Table 1: Prophet Moses swept to the river

\begin{tabular}{|l|c|c|c|c|}
\hline \multicolumn{1}{|c|}{$\begin{array}{c}\text { Types of } \\
\text { Questions }\end{array}$} & $\begin{array}{c}\text { Decreased } \\
\text { achievement } \\
\text { among the } \\
\text { students }\end{array}$ & $\begin{array}{c}\text { Unchanged } \\
\text { achievement }\end{array}$ & $\begin{array}{c}\text { Improvement in } \\
\text { students' } \\
\text { achievement }\end{array}$ & $\begin{array}{c}\text { Percentage of } \\
\text { improvement }\end{array}$ \\
\hline Vocabulary & 4 & 1 & 18 & 78 \\
\hline Clause & - & - & 23 & 100 \\
\hline
\end{tabular}

Table 1 shows the differences in students' achievement in answering language acquisition questions before and after watching the video of Prophet Moses swept to the River. The study found that the number of students who achieved an increase in Arabic vocabulary after watching Arabic videos is as high as $78 \%$, compared with before watching the videos. There are four students who scored higher before watching the video than after watching it. This is because they had a difficult time identifying words that were spoken while watching, even when it was repeated several times. Since this episode was the first video they watched, students were still not familiar with words through the subtitles. For the Arabic language test, there was a $100 \%$ increase observed among the students after watching the video. However, they found it difficult to construct long sentences correctly even though they knew the vocabulary related to the clause.

Table 2: Prophet Moses crossed the sea

\begin{tabular}{|l|c|c|c|c|}
\hline \multicolumn{1}{|c|}{$\begin{array}{c}\text { Types of } \\
\text { Questions }\end{array}$} & $\begin{array}{c}\text { Decreased } \\
\text { achievement } \\
\text { among the } \\
\text { students }\end{array}$ & $\begin{array}{c}\text { Unchanged } \\
\text { achievement }\end{array}$ & $\begin{array}{c}\text { Improvement in } \\
\text { students' } \\
\text { achievement }\end{array}$ & $\begin{array}{c}\text { Percentage of } \\
\text { improvement }\end{array}$ \\
\hline Vocabulary & 2 & - & 21 & 91 \\
\hline Clause & 3 & - & 22 & 95 \\
\hline
\end{tabular}

In Table 2, most of the students showed an increase of vocabulary after watching the video of Prophet Moses Crossing the Ocean. Similar to the clause test, only one student showed no improvement after watching the video. Others showed an increase of $95 \%$.

Table 3: Prophet Moses taking live coals

\begin{tabular}{|l|c|c|c|c|}
\hline \multicolumn{1}{|c|}{$\begin{array}{c}\text { Types of } \\
\text { Questions }\end{array}$} & $\begin{array}{c}\text { Decreased } \\
\text { achievement } \\
\text { among the } \\
\text { students }\end{array}$ & $\begin{array}{c}\text { Unchanged } \\
\text { achievement }\end{array}$ & $\begin{array}{c}\text { Improvement in } \\
\text { students' } \\
\text { achievement }\end{array}$ & $\begin{array}{c}\text { Percentage of } \\
\text { improvement }\end{array}$ \\
\hline Vocabulary & - & - & 23 & 100 \\
\hline Clause & - & - & 23 & 100 \\
\hline
\end{tabular}

Table 3 shows an increase in students' achievement in vocabulary and clause tests up to $100 \%$ after watching the video of Moses Taking Coals. This shows that the students are more compatible with the presence of subtitles in understanding the Arabic dialogues in the videos that they are watching. The improvement in scores of vocabulary and clause tests were notable up to $100 \%$ for this video also proved that subtitles helped students to acquire vocabulary as well as Arabic clauses. 
Table 4: Prophet Moses yanked Pharaoh's beard

\begin{tabular}{|l|c|c|c|c|}
\hline \multicolumn{1}{|c|}{$\begin{array}{c}\text { Types of } \\
\text { Questions }\end{array}$} & $\begin{array}{c}\text { Decreased } \\
\text { achievement } \\
\text { among the } \\
\text { students }\end{array}$ & $\begin{array}{c}\text { Unchanged } \\
\text { achievement }\end{array}$ & $\begin{array}{c}\text { Improvement in } \\
\text { students' } \\
\text { achievement }\end{array}$ & $\begin{array}{c}\text { Percentage of } \\
\text { improvement }\end{array}$ \\
\hline Vocabulary & - & - & 23 & 100 \\
\hline Clause & - & - & 23 & 100 \\
\hline
\end{tabular}

Table 4 also shows an increase of $100 \%$ in both the vocabulary and clause test. After watching the four videos, students were able to understand the function of subtitles in capturing words and acquiring language. They are more proficient in using subtitles in the videos they watched so that they are able to recognize, remember and rewrite Arabic vocabulary and clauses derived from the videos they watched.

\section{Comparative analysis of individual achievement for $\mathbf{2 3}$ students in vocabulary and clause tests}

Table 5: Analysis of Vocabulary Acquisition Test

(Total Question 24)

\begin{tabular}{|c|c|c|c|c|c|}
\hline \multirow{2}{*}{ Respondents } & \multicolumn{2}{|c|}{ Test Before (\%) } & \multicolumn{2}{c|}{ Test After (\%) } & \multirow{2}{*}{ Increase } \\
\cline { 2 - 5 } & Exact Figures & Percentage & $\begin{array}{c}\text { Exact } \\
\text { Figures }\end{array}$ & Percentage \\
\hline 1 & 5 & 21 & 16 & 67 & 46 \\
\hline 2 & 8 & 34 & 15 & 63 & 29 \\
\hline 3 & 5 & 21 & 16 & 67 & 46 \\
\hline 4 & 4 & 17 & 15 & 63 & 46 \\
\hline 5 & 10 & 42 & 12 & 50 & 8 \\
\hline 6 & 8 & 34 & 16 & 67 & 33 \\
\hline 7 & 7 & 29 & 16 & 67 & 38 \\
\hline 8 & 9 & 38 & 22 & 92 & 54 \\
\hline 9 & 6 & 25 & 16 & 67 & 42 \\
\hline 10 & 5 & 21 & 15 & 63 & 42 \\
\hline 11 & 7 & 29 & 18 & 76 & 46 \\
\hline 12 & 6 & 25 & 19 & 80 & 54 \\
\hline 13 & 5 & 21 & 18 & 76 & 54 \\
\hline 14 & 6 & 25 & 16 & 67 & 42 \\
\hline 15 & 5 & 21 & 15 & 63 & 42 \\
\hline 16 & 6 & 25 & 17 & 71 & 46 \\
\hline 17 & 4 & 17 & 18 & 76 & 58 \\
\hline 18 & 8 & 34 & 18 & 76 & 42 \\
\hline 19 & 5 & 21 & 14 & 59 & 38 \\
\hline 20 & 3 & 13 & 16 & 67 & 54 \\
\hline 21 & 4 & 17 & 15 & 63 & 46 \\
\hline 22 & 6 & 25 & 18 & 76 & 50 \\
\hline 23 & 5 & 21 & 20 & 84 & 63 \\
\hline
\end{tabular}


The table above shows a comparison of each student's achievement in the test before watching the video and after watching the video. The analysis showed that $30 \%$ of students achieved a $50 \%$ increase in vocabulary test after watching the video, while another $70 \%$ also showed a moderate improvement. However, none of the students showed a decrease in achievement after watching the video.

Table 6: Analysis of The Clause Acquisition Test (Total Question 24)

\begin{tabular}{|c|c|c|c|c|c|}
\hline \multirow[t]{2}{*}{ Respondents } & \multicolumn{2}{|c|}{ Test Before } & \multicolumn{2}{|c|}{ Test After } & \multirow[t]{2}{*}{$\%$ Increase } \\
\hline & Exact Figure & Percentage & $\begin{array}{l}\text { Exact } \\
\text { Figure }\end{array}$ & Percentage & \\
\hline 1 & 3 & 13 & 20 & 84 & 29 \\
\hline 2 & 1 & 4 & 20 & 84 & 79 \\
\hline 3 & 3 & 13 & 16 & 67 & 54 \\
\hline 4 & 3 & 13 & 17 & 71 & 58 \\
\hline 5 & 4 & 17 & 10 & 42 & 25 \\
\hline 6 & 4 & 19 & 18 & 76 & 58 \\
\hline 7 & 2 & 8 & 15 & 63 & 54 \\
\hline 8 & 1 & 4 & 21 & 88 & 83 \\
\hline 9 & 0 & 0 & 15 & 63 & 63 \\
\hline 10 & 4 & 17 & 15 & 63 & 46 \\
\hline 11 & 4 & 17 & 22 & 92 & 92 \\
\hline 12 & 7 & 29 & 22 & 92 & 63 \\
\hline 13 & 4 & 17 & 17 & 71 & 54 \\
\hline 14 & 2 & 8 & 16 & 67 & 58 \\
\hline 15 & 0 & 0 & 21 & 88 & 88 \\
\hline 16 & 3 & 13 & 19 & 80 & 67 \\
\hline 17 & 3 & 13 & 19 & 80 & 67 \\
\hline 18 & 3 & 13 & 19 & 80 & 67 \\
\hline 19 & 0 & 0 & 16 & 67 & 67 \\
\hline 20 & 3 & 13 & 14 & 59 & 46 \\
\hline 21 & 5 & 21 & 20 & 84 & 63 \\
\hline 22 & 4 & 17 & 21 & 88 & 71 \\
\hline 23 & 7 & 29 & 18 & 76 & 46 \\
\hline
\end{tabular}

The comparative analysis of individual achievement in the clause test showed a total of 18 students, which is $78 \%$ achieved an increase of more than $50 \%$ for the clause test after watching the video. The remaining $22 \%$ also showed improvement, but at a lower rate. However, none of the students showed a decrease in sentence acquisition rates after watching the video.

\section{Research Findings}

The results show that students' mastery of Arabic vocabulary and clauses are still in poor condition. This is because in the test run before watching the video shows none of the students has achieved more than $50 \%$ from the vocabulary test or the clause test. The highest score for the vocabulary test was $42 \%$ while the highest achievement in the clause test was only $29 \%$. 
However, improvement in scores occurred in both tests after students watched the video. The highest achievement in vocabulary and clause tests after watching the video was $92 \%$. In the vocabulary test, all the students achieved $50 \%$ while in the test clause, only one student failed $50 \%$. The students' achievement in the tests after watching the video demonstrates the process of acquiring vocabulary as well as the Arabic clause among the students after watching the videos and subtitles. This increase indirectly proves the effectiveness of the learning strategy with subtitles in helping students acquire language. Although there are spelling mistakes involving Arabic grammar in the students' answers, they can be considered as having the ability to understand and pronounce the vocabulary as heard in the video they watched.

\section{Conclusion}

Students' knowledge and mastery of the language can be improved through video viewing along with subtitles. The use of Arabic videos or subtitles to be shown to students in the classroom can be considered as one of the most effective strategies in Arabic language teaching, especially in improving students' listening and speaking skills. In addition to attracting students to learn the language, video shows can also evoke a fun learning atmosphere such as being in a cinema. This process of acquiring vocabulary is enhanced by the role of teachers and lecturers in reviewing and correcting spelling errors and demonstrating proper writing. The increase in test scores taken indicates a significant increase in vocabulary and acquisition of Arabic language among students through subtitles. This proves that subtitles is one of the medium of acquiring Arabic vocabulary which indirectly helps students to increase the range of vocabulary in learning.

\section{References}

Alabbasi, A. (2009). Towards a constructive cultural interaction via audio-visual translation (Arabic-English). $12^{\text {th }}$ Conference Proceeding of International Translation, pp. 179-189.

Baharudin, H. (2017). Strategi dan Teknik Terjemahan Novel Arab Dalam Kalangan Pelajar Universiti. GEMA OnlineTM Journal of Language Studies. http://www.researchgate.net/publication/321370840. Retrieved on 21 March 2018

Omar, H. C. (2006). Penterjemahan Audiovisual Televisyen. Bangi: Penerbit Universiti Kebangsaan Malaysia.

Nathesan. S. (2011). Leksikon: Kosa Kata Bahasa, Dewan Bahasa Ogos 2011, Jilid 11 Bil.08, Dewan Bahasa dan Pustaka, Kuala Lumpur.

Mat, N. N. T., \& Ahmad, M. (2014). Persepktif Awal Kaedah Terjemahan Dalam Pengajaran Bahasa Kedua. Prosiding Seminar Pengajaran \& Pembelajaran Bahasa Arab 2014.

Abdul Rahman, N. E. (2014). Penterjemahan audiovisual: Kajian sari kata Arab-Melayu. Tesis Phd Fakulti Pengajian Islam, Universiti Kebangsaan Malaysia.

Ardi, N., \& Samsir, S. Q. M. (2017). Terjemahan: Strategi pengajaran bahasa Melayu sebagai bahasa asing. Prosiding Penterjemahan Antarabangsa Ke-15, hlm. 216-226.

Yusoff, R., \& Che Omar, H. (2009). Satu kajian kes terhadap pemahaman filem dan kepentingan penterjemahan. Prosiding Penterjemahan Antarabangsa Ke-12, hlm. 537-545. 